\title{
Long-term variation of the Bay of Brest ecosystem: benthic-pelagic coupling revisited
}

\author{
Laurent Chauvaud, Frédéric Jean, Olivier Ragueneau, Gérard Thouzeau* \\ Université de Bretagne Occidentale-Institut Universitaire Européen d'Etudes Marines, UMR 6539 CNRS, \\ Technopôle Brest-Iroise, Place Copernic, 29280 Plouzané, France
}

\begin{abstract}
Observations over the last 20 yr of the development of pelagic and benthic communities of a western European coastal ecosystem (Bay of Brest) provide complementary hypotheses to the 'silicic acid pump' hypothesis. An increase in nitrogen inputs, independent of silicic acid levels, has lowered the Si:N molar ratios during the last 20 yr in river discharges. Since 1981, maximum concentrations of chlorophyll a during the first spring bloom of the annual cycle have decreased, in contrast to the subsequent spring and summer blooms. Concomitantly, extensive spreading of an exotic gastropod Crepidula fornicata has modified the trophic structure of benthic communities by increasing suspension-feeder biomass. The following hypotheses on ecosystem functioning are made: (1) the decrease of chlorophyll biomass during the first spring bloom results from silicic acid limitation and increased suspension feeder activity, (2) benthic filtration and biodeposition activities enhance biogenic silica retention at the sediment-water interface, and (3) recycling of trapped biogenic silica maintains diatom populations by providing silicic acid in summer and reduces primary production seasonality. These hypotheses suggest that benthic organisms control the export rate of biogenic silica towards the open-water ocean and thus the specific composition of secondary phytoplankton blooms in the Bay.
\end{abstract}

KEY WORDS: Coastal ecosystem $\cdot$ Benthic-pelagic coupling $\cdot$ Long-term fluctuations $\cdot$ Silicon cycle

\section{INTRODUCTION}

Increasing nutrient inputs into coastal ecosystems are often accompanied by eutrophication phenomena and structural changes within the phytoplankton community (Smayda 1990, Billen et al. 1991, Humborg et al. 1997). In such systems, the increase of anthropogenic nitrogen $(\mathrm{N})$ and phosphorus $(\mathrm{P})$ inputs into rivers, as well as enhanced accumulation of biogenic silica (BSi) in sediments, lowers the $\mathrm{Si}: \mathrm{N}$ and $\mathrm{Si}: \mathrm{P}$ ratios in the neighbouring coastal waters, affecting phytoplankton specific composition and allowing for silicic acid (silicate) limitation of primary production in diatom-dominated systems (Meybeck \& Helmer 1989, Smayda 1990, Le Pape et al. 1996, Del Amo et al. $1997 a, b]$. It is obvious that the most affected part of the

\footnotetext{
- Corresponding author.

E-mail: gerard.thouzeau@univ-brest.fr
}

phytoplankton community is the diatoms (Officer \& Ryther 1980, Smayda 1990, Conley \& Malone 1992). The decrease in their abundance or dominance (van Bennekom et al. 1975, Bodeanu 1990), and more generally the shift from siliceous populations (diatoms) to non-siliceous ones (flagellates; Billen et al. 1991, Fisher et al. 1992) together with the possible emergence of new toxic species (Smayda 1990, Anderson 1995) have been described as a consequence of $\mathrm{N}$ and $\mathrm{P}$ enrichments.

The Bay of Brest (France) constitutes a coastal macrotidal ecosystem (maximum tidal amplitude: $8 \mathrm{~m}_{\text {; }}$ tide periodicity: $12 \mathrm{~h} 15 \mathrm{~min}_{i}$ maximum tidal currents: $2.6 \mathrm{~m} \mathrm{~s}^{-1}$ ) that receives increasing nutrient inputs of anthropogenic origin (Dauchez et al. 1991, Daniel 1995, Le Pape et al. 1996); it is influenced by both freshwater inputs from rivers and fast mixing exchanges with waters from the Atlantic Ocean (Salomon \& Breton 1991). Previous studies have demonstrated the influence exerted by tides on primary production 
dynamics to be the most important (Quéguiner 1982, Ragueneau 1994, Daniel 1995, Le Pape 1996, Ragueneau et al. 1996). In particular, diatom-dominated phytoplankton blooms have been shown to respond to decreasing tidal mixing (Ragueneau et al. 1996). During the last $20 \mathrm{yr}$, nitrate concentrations in rivers have doubled leading to a long-term decrease in Si: $\mathrm{N}$ molar ratios (silicic acid: nitrate + nitrite + ammonium) during summer in coastal seawaters, from 2 in 1975 to 0.33 in 1993 (Le Pape et al. 1996). In the literature, the symptoms of eutrophication cover many aspects of ecosystem functioning including increase in phytoplankton primary production and biomass, oxygen depletion, changes of the phytoplankton community structure with the emergence of harmful or nuisance blooms of microalgae, loss or alteration of macrophyte communities and changes in higher trophic levels (see Smayda 1990, Gray 1992). The Bay of Brest has not undergone any event characterised by high phytoplankton biomass liable to cause oxygen depletion (Le Pape et al. 1996). Numerous studies (Breton 1993, Ragueneau 1994, Ragueneau et al. 1994, Daniel 1995, Del Amo 1996, Le Pape 1996, Le Pape et al. 1996, Del Amo et al. $1997 \mathrm{a}, \mathrm{b})$ have demonstrated that the imbalance between silicic acid and $N$ loads is high in the bay waters during spring and summer, but until 1993 only very few transient non-siliceous phytoplankton blooms occurred in the Bay of Brest (see Del Amo et al. 1997b). Resistance to effects of increased nutrient input (both increased primary production and phytoplankton species shifts) has been attributed to several additional factors, such as the relative fast flushing time (Delmas 1981, Delmas \& Tréguer 1983), the time-lag between $N$ inputs in winter and primary production in spring and summer (Le Pape et al. 1996, Del Amo et al. 1997a), BSi recycling, both in the water column and at the sediment-water interface (Ragueneau et al. 1994) and strong tidally induced vertical mixing. The latter, which is not favourable to flagellates (Margalef 1978, Ragueneau et al. 1996), would facilitate the replenishment of surface waters in silicic acid recycled at the sediment-water interface during the remaining productive period (see the role of a 'silicic acid pump in coastal waters' in Del Amo et al. 1997a,b).

Deep waters are usually considered as a receiver compartment dependent on, though decoupled from, primary production in the water column. It has been shown that seston deposition follows the seasonality of primary production (Deuser et al. 1981, Billet et al. 1983, Graf 1989). The influence exerted by benthic mineralization on pelagic production has also been demonstrated in coastal systems (Nixon 1981, Pomroy et al. 1983, Hopkinson 1987). However, only a few studies have considered the direct feedback of benthos through energy storage in the organisms or control of phytoplankton populations by benthic filter feeders (Ott \& Fedra 1977, Ott 1981, Cloern 1982, Officer et al. 1982, Nichols 1985, Loo \& Rosenberg 1989, Herman \& Sholten 1990). The present paper considers benthicpelagic coupling in the Bay of Brest and the way this ecosystem 'withstands' increased nutrient input and the subsequent detrimental effects. In fact, the Bay of Brest sustains benthic communities whose structure is characteristic of eutrophicated ecosystems (Pearson \& Rosenberg 1978, Cederwall \& Elmgren 1990, Rosenberg et al. 1990). According to the Gray-scale (1992), the shallowest macrobenthic communities show the first symptoms of eutrophication (Grall \& Glémarec 1997). The changes in pelagic and benthic compartments during the last $20 \mathrm{yr}$ enable us to reconcile contradictory results about changes in pelagic and benthic communities. The Si:N distrophy has indeed allowed for silicic acid to play a major role in the control of diatom dominance. Here we hypothesize that the silicic pump by which $\mathrm{Si}$ is retained within the system and made available to summer diatoms via benthic dissolution and vertical mixing (Del Amo et al. 1997b) is in fact dependent on benthic suspension-feeder activity.

\section{MATERIAL AND METHODS}

Study site. The Bay of Brest is a $180 \mathrm{~km}^{2}$ semienclosed marine ecosystem connected to shelf waters (Iroise Sea) by a narrow ( $2 \mathrm{~km}$ wide) and deep (40 m) strait (Fig. 1). The bay is a shallow basin with $50 \%$ of its surface shallower than $5 \mathrm{~m}$ (average depth $8 \mathrm{~m}$ ). There are 5 watersheds responsible for freshwater inputs in the bay, but those from the 2 main rivers, the Aulne $\left(1842 \mathrm{~km}^{2}\right)$, and the Elorn $\left(402 \mathrm{~km}^{2}\right)$, comprise $80 \%$ of total freshwater inputs. Tidal action induces short-term variability in hydrological parameters and enhances mixing of the water masses (see Quéguiner \& Tréguer 1984, Salomon \& Breton 1991, Daniel et al. 1995, Chauvaud et al. 1996, 1998). Tidal variation reaches $8 \mathrm{~m}$ during spring tides, which represents an oscillating volume of $40 \%$ of the high tide volume.

Phytoplankton biomass and communities. The source and nature of the data processed throughout this study are listed in Table 1. Surface-water chlorophyll a (chl a) and phaeophytin concentrations in 1994, 1995 (Chauvaud et al. 1998) and 1996 (this study) were added to the dataset previously compiled by Le Pape (1996). Bottom-water data, either unpublished or collected from the literature, were also compiled to be added to those determined between 1994 and 1996. The annually integrated chlorophyll biomass was estimated from chl a concentrations. Chl $a$ and phaeophytin concentrations in 1996 were estimated using a calibrated Turner 111 fluorometer according to 


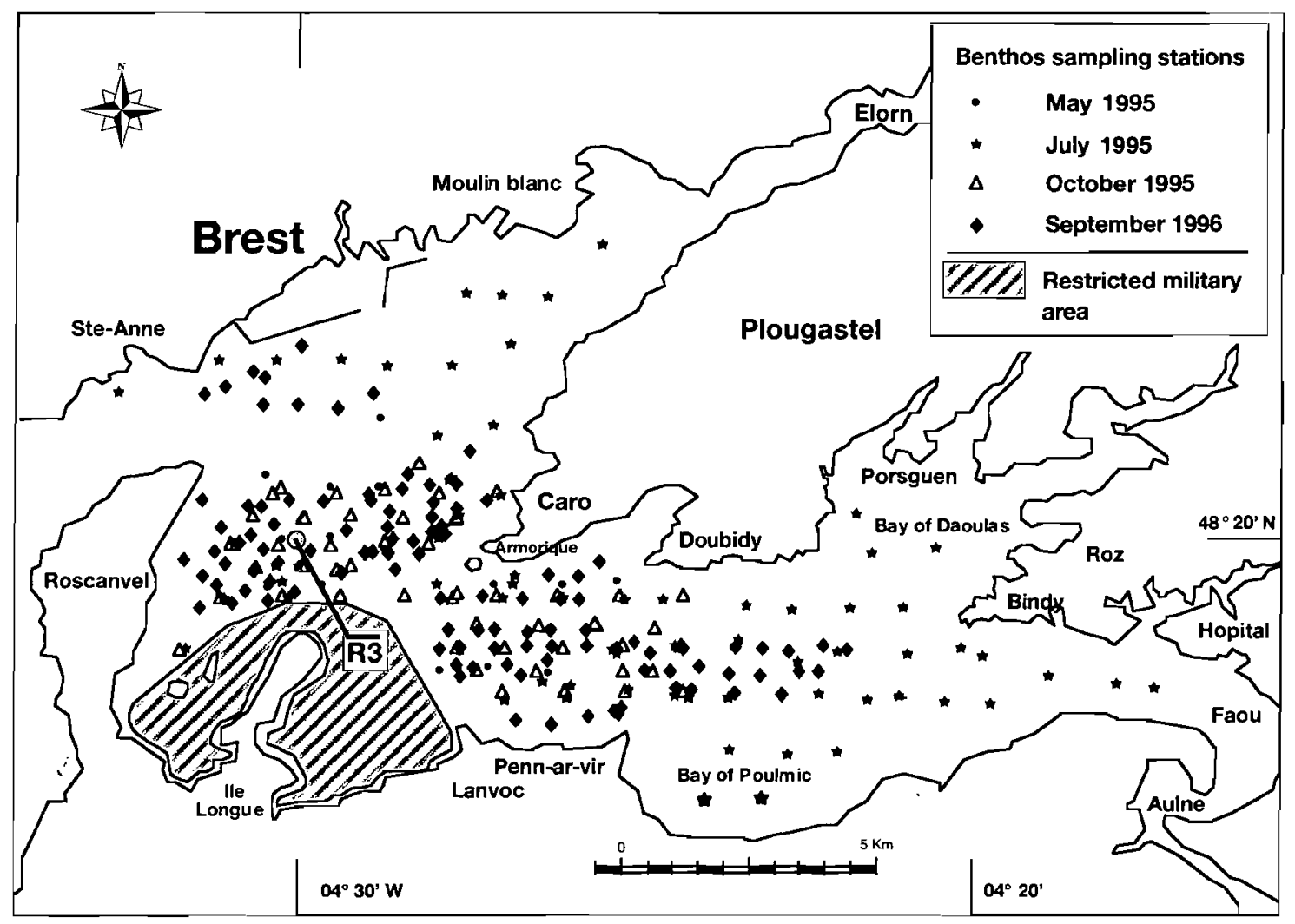

Fig. 1. Study area and location of sampling stations. Water column parameters were measured at Stn R3. Locations of benthos sampling stations were drawn from Chauvaud (1998)

Yentsch \& Menzel (1963) and Lorenzen (1967; see also Chauvaud et al. 1998).

Benthic communities. Epibenthic megafauna, including Crepidula fornicata, were sampled using a videomonitored sled-dredge AQUAREVE (Thouzeau \& Hily 1986, Thouzeau \& Lehay 1988, Thouzeau 1989) modified by Thouzeau et al. (1991). AQUAREVE works like an epibenthic sled-dredge sliding on the bottom (tow speed 1 to 1.5 knots) while its knife slices the upper $5 \mathrm{~cm}$ of sediments. The working of the dredge is monitored via an underwater video camera mounted on the sled and turned toward the opening of the box. While in operation, instantaneous picture transmission allows the ship to stop the tow before the box overfills and to control dredging efficiency. The distance travelled on the bottom is measured by an odometric wheel providing a precise estimate of the tow length. The collecting box ( $0.97 \mathrm{~m}$ wide $\times 0.4 \mathrm{~m}$ high) is a rectangular steel box drilled with regularly spaced holes of $10 \mathrm{~mm}$ in diameter. A box-closing device triggers when the sled leaves the bottom. Samples were collected in May, July and October 1995 and September 1996 (Fig. 1; see Chauvaud, 1998). C. fornicata biomass (wet and dry weight) was estimated for each tow, each biosedimentary strata and for the whole Bay (Thouzeau et al. in press).

\section{RESULTS}

\section{Main features of the Bay of Brest ecosystem}

\section{River flow-rates}

Comparing daily flow-rates of the Aulne and Elorn, recorded between 1977 and 1995, has enabled us to select the Aulne flow rate as a climate indicator over a $30 \mathrm{yr}$ period (linear correlation between the 2 sets of data: $r^{2}=0.83$ with $p<0.01$ ). A marked seasonal variation of river flow is observed whatever the year considered (Fig. 2). Inter-annual variability is mainly the result of fluctuations in winter rainfall. The geometric moving average was calculated on 183 Julian days between 1977 and 1995; it did not reveal any characteristic trend in weather conditions during the last $19 \mathrm{yr}$, except for a major increase in flow-rate between 1992 and 1995. 
Table 1. Bay of Brest. Sources and parameters measured in the water column between 1977 and 1996. $N_{b}=$ number of bottom measurements, $\mathrm{N}_{\mathrm{s}}=$ number of surface measurements. RNO: Réseau National d'Observation (French Ministry of Environment)

\begin{tabular}{|c|c|c|c|c|c|}
\hline Year & $N_{b}$ & Bottom & \multicolumn{2}{|c|}{ Measured parameters } & Source \\
\hline 1977 & & & 36 & $\begin{array}{l}\text { Nutrients } \\
\text { Chl a } \\
\text { Phaeophytin }\end{array}$ & RNO data \\
\hline 1981 & 18 & $\begin{array}{l}\text { Chl a } \\
\text { Phaeophytin }\end{array}$ & 35 & $\begin{array}{l}\text { Nutrients } \\
\text { Chl a } \\
\text { Phaeophytin }\end{array}$ & $\begin{array}{l}\text { Quéguiner (1982) } \\
\text { RNO data }\end{array}$ \\
\hline 1982 & 43 & $\begin{array}{l}\text { Chl a } \\
\text { Phaeophytin }\end{array}$ & 49 & $\begin{array}{l}\text { Nutrients } \\
\text { Chl a } \\
\text { Phaeophytin }\end{array}$ & $\begin{array}{l}\text { Quéguiner (1982) } \\
\text { RNO data }\end{array}$ \\
\hline 1983 & 18 & $\begin{array}{l}\text { Chl a } \\
\text { Phaeophytin }\end{array}$ & 33 & $\begin{array}{l}\text { Nutrients } \\
\text { Chl a } \\
\text { Phaeophytin }\end{array}$ & Hafsaoui (1984) \\
\hline 1991 & 12 & $\begin{array}{l}\text { Nutrients } \\
\text { Chl a } \\
\text { Phaeophytin }\end{array}$ & 30 & $\begin{array}{l}\text { Nutrients } \\
\text { Chl a } \\
\text { Phaeophytin }\end{array}$ & Daniel (1995) \\
\hline 1992 & 20 & $\begin{array}{l}\text { Nutrients } \\
\text { Chl a } \\
\text { Phaeophytin }\end{array}$ & 28 & $\begin{array}{l}\text { Nutrients } \\
\text { Chl a } \\
\text { Phaeophytin }\end{array}$ & $\begin{array}{l}\text { Ragueneau (1994) } \\
\text { and Daniel (1995) }\end{array}$ \\
\hline 1993 & 27 & $\begin{array}{l}\text { Nutrients } \\
\text { Chl a } \\
\text { Phaeophytin }\end{array}$ & 27 & $\begin{array}{l}\text { Nutrients } \\
\text { Chl a } \\
\text { Phaeophytin } \\
\text { Phytoplankton } \\
\text { Specific composition }\end{array}$ & $\begin{array}{l}\text { Le Pape (1996), } \\
\text { Del Amo (1996), and } \\
\text { Del Amo et al. (1997a,b) }\end{array}$ \\
\hline 1994 & 28 & $\begin{array}{l}\text { Chl a } \\
\text { Phaeophytin }\end{array}$ & 28 & $\begin{array}{l}\text { Chl a } \\
\text { Phaeophytin }\end{array}$ & Chauvaud et al. (1996) \\
\hline 1995 & 32 & $\begin{array}{l}\text { Chl a } \\
\text { Phaeophytin }\end{array}$ & 33 & $\begin{array}{l}\text { Chl a } \\
\text { Phaeophytin }\end{array}$ & Chauvaud et al. (1998) \\
\hline 1996 & 37 & $\begin{array}{l}\text { Chl a } \\
\text { Phaeophytin }\end{array}$ & 37 & $\begin{array}{l}\text { Chl a } \\
\text { Phaeophytin }\end{array}$ & This study \\
\hline
\end{tabular}

Nutrient inputs and phytoplankton biomass

Nutrients. During the last $30 \mathrm{yr}$, an increase in agricultural production (crop production, fertilizer levels, number of pigs) in the Aulne and Elorn catchments has created large discharges of $\mathrm{N}$ compounds to the Bay of Brest (Cann 1995). Tréguer \& Quéguiner (1989) have shown a 10-fold increase of $\mathrm{N}$ inputs to the bay since the beginning of this century. As most of these nitrogenous compounds are inorganic (98\%; Cann 1995), they can be directly used for primary production (Le Pape 1996). Between 1975 and 1991, overall concentrations of nitrite and nitrate at the freshwater/seawater limit increased yearly (Joanny et al. 1993; Fig. 3a). The yearly averaged

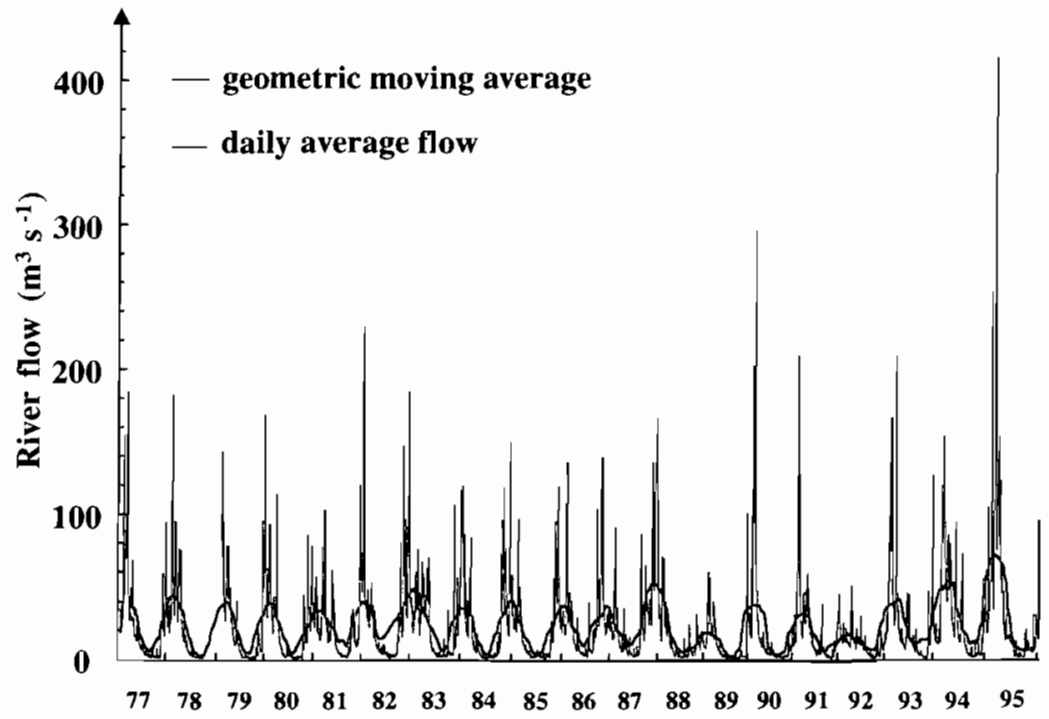

Fig. 2. Average daily flow-rate $\left(\mathrm{m}^{3} \mathrm{~s}^{-1}\right)$ of the Aulne river between 1977 and 1995 (data provided by the Agence de Bassin Loire-Bretagne) and geometric moving average calculated on 183 Julian days 

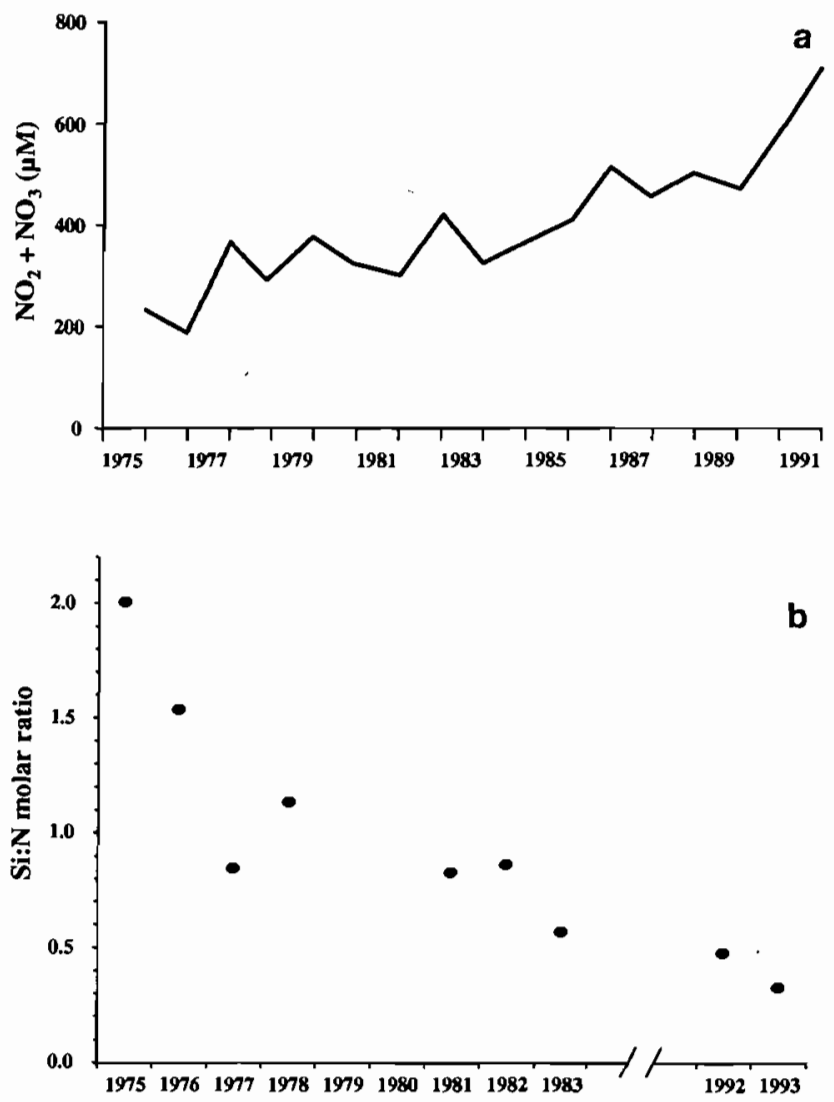

Fig. 3. (a) Nitrate + nitrite concentrations (mean annual concentrations in $\mu \mathrm{M}$ ) in the Aulne at the limit between fresh and marine waters (redrawn from Joanny et al. 1993); (b) Si:N molar ratios determined at Stn R3 in surface waters during summer, when nutrients are limiting (redrawn from Le Pape et al. 1996)

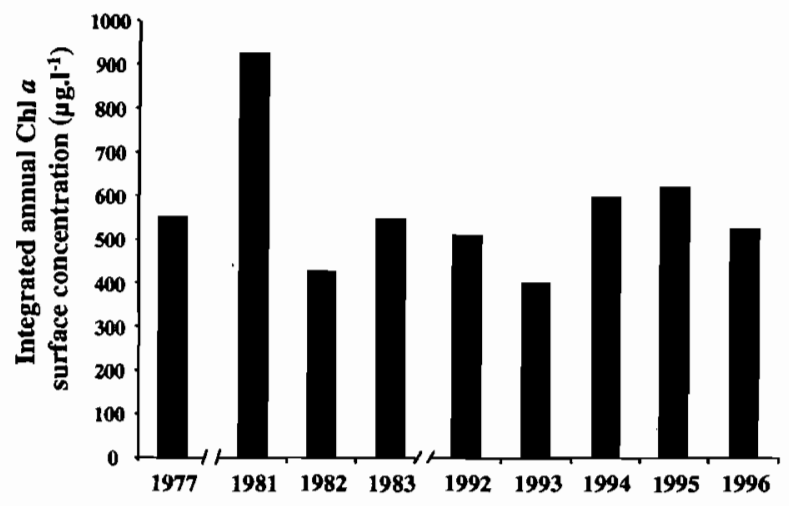

Fig. 4. Integrated chl a biomass ( $\left.\mu \mathrm{g} \mathrm{l}^{-1}\right)$ in surface waters during the growing season between 15 February and 3 November 1977, 1981-83, and 1992-96

mum chl a concentrations in surface waters have decreased since 1981. However, near-bottom chlorophyll biomass decreased between 1981 and 1993, but increased in later years. Such trends reduce the seasonality of chlorophyll biomass. A seasonality index, $\alpha$ (Berger \& Wefer 1990), was calculated according to the following relationship: $\alpha=(260-\beta)$, where $\beta$ is the time (days) required to reach half of the value of the integrated chl a biomass in surface waters estimated over 260 d, i.e. the time elapsed between 15 February and 3 November (first and last dates common to all the years investigated). A noticeable decrease of this index was observed over the study period (Fig, 6), thus confirming the time extension of the high biomass period. increase of nitrate was about $23 \mu \mathrm{M}$ in the Aulne and $72 \mu \mathrm{M}$ in the Elorn during this period (Joanny et al. 1993, Daniel 1995, Del Amo 1996, Le Pape et al. 1996). The annual input of dissolved inorganic nitrogen (DIN) from terrestrial origin in the Bay has been estimated to be $8000 \mathrm{t}$ (Daniel 1995). This increase in $N$ input has lowered Si:N molar ratios during the last $20 \mathrm{yr}$ (Fig. 3b). This ratio was 6 times higher in 1975 than in 1993 (Le Pape 1996, Le Pape et al. 1996).

Chl a. Though the annually integrated chlorophyll biomass does not exhibit any characteristic long-term trend (Fig. 4), a noticeable reduction in the first spring bloom of the annual cycle can be observed over the years, in contrast to the subsequent secondary blooms (Fig. 5). During the first spring bloom of the year, maxi-

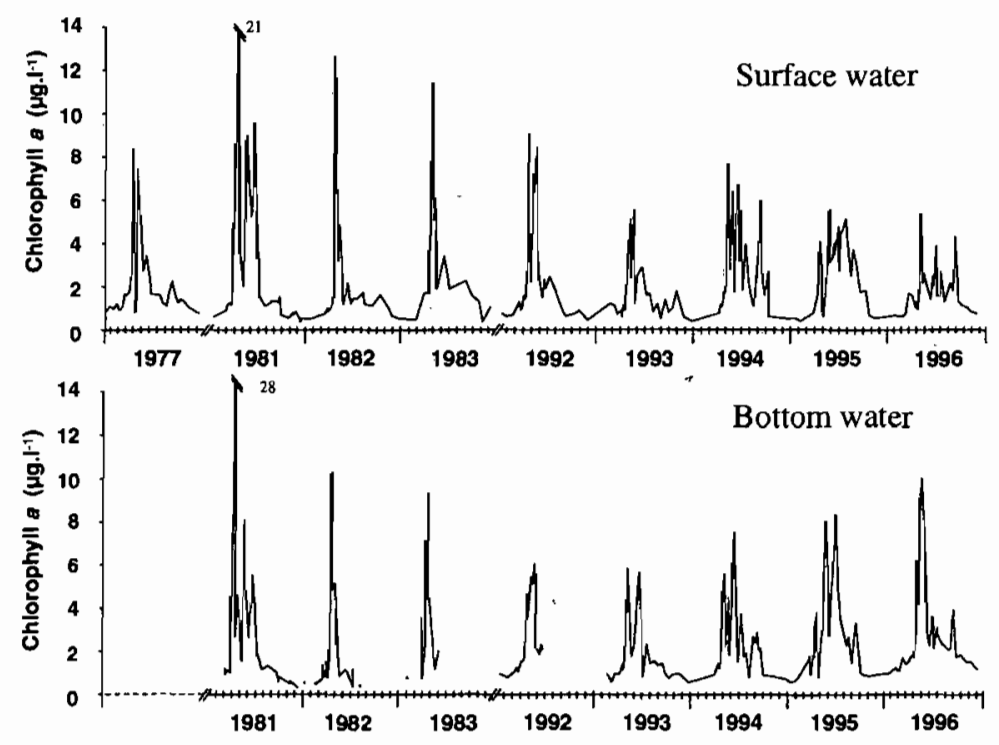

Fig. 5. Surface- and bottom-water chl a concentrations $\left(\mu \mathrm{g} \mathrm{l}^{-1}\right)$ determined at Stn R3 between 1977 and 1996 


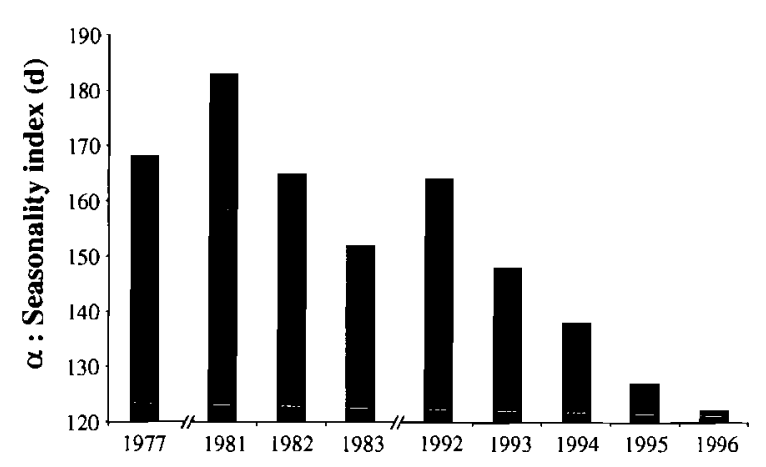

Fig. 6. Seasonality index, $\alpha(\alpha=260-\beta)$, where $\beta$ is the number of days required to obtain half the integrated biomass assessed over $260 \mathrm{~d}$ (from 15 February to 3 November) et al. in press). The area covered by this species expanded from $45 \mathrm{~km}^{2}$ in 1978 (Coum 1979) to $90 \mathrm{~km}^{2}$ in 1995 (Fig. 7; Chauvaud 1998). Its biomass was $12878 \mathrm{t}$ dry weight (DW) in 1995 and varied between 0 and $6900 \mathrm{~g} \mathrm{DW} \mathrm{m}^{-2}$, depending on sediment type. The faeces and pseudo-faeces produced by $C$. fornicata represented $846000 \mathrm{t} \mathrm{yr}^{-1}$ wet weight $(\mathrm{WW})$ and $11324 \mathrm{t}$ of dry organic matter. These biodeposits, together with the constant extension of shoals, caused noticeable alterations in the specific composition and structure of benthic megafauna populations. The impact of the extensive spreading of $C$. fornicata onto bottoms like muddy sands and gravels, coralline algae (maerl) and muds previously colonised by specific communities
Phytoplankton species composition

The specific composition of successive phytoplankton blooms in the Bay of Brest was only weakly influenced by increasing $\mathrm{N}$ fertilization (Del Amo 1996, Del Amo et al. 1997b). Thalassiosira spp., Rhizosolenia spp. and Chaetoceros spp. constituting the characteristic succession of diatoms in the Bay of Brest (Quéguiner 1982) have been regularly observed (Ragueneau 1994, Daniel 1995, Del Amo et al. 1997b, Chauvaud et al. 1998). In 1993 and 1995 however, the development of blooms of Dinophysis spp., Gymnodinium cf. nagasakiense or Phaeocystis pouchetii was observed (Nézan et al. 1996, Del Amo et al. $1997 \mathrm{~b}$ ). For the first time $G$. cf. nagasakiense (a toxic dinoflagellate) dominated the phytoplankton community during the summer of 1995 (Nézan et al. 1996).

Benthic megafauna communities

Many studies on benthic communities have shown the dominance of suspension feeders in the Bay of Brest (Hily 1984, 1989, 1991, Jean 1994, Jean \& Thouzeau 1995, Grall \& Glémarec 1997, Chauvaud 1998). Since its introduction in 1950, the gastropod Crepidula fornicata has been proliferating and is today the main benthic suspension feeder in the Bay (Chauvaud 1998, Thouzeau
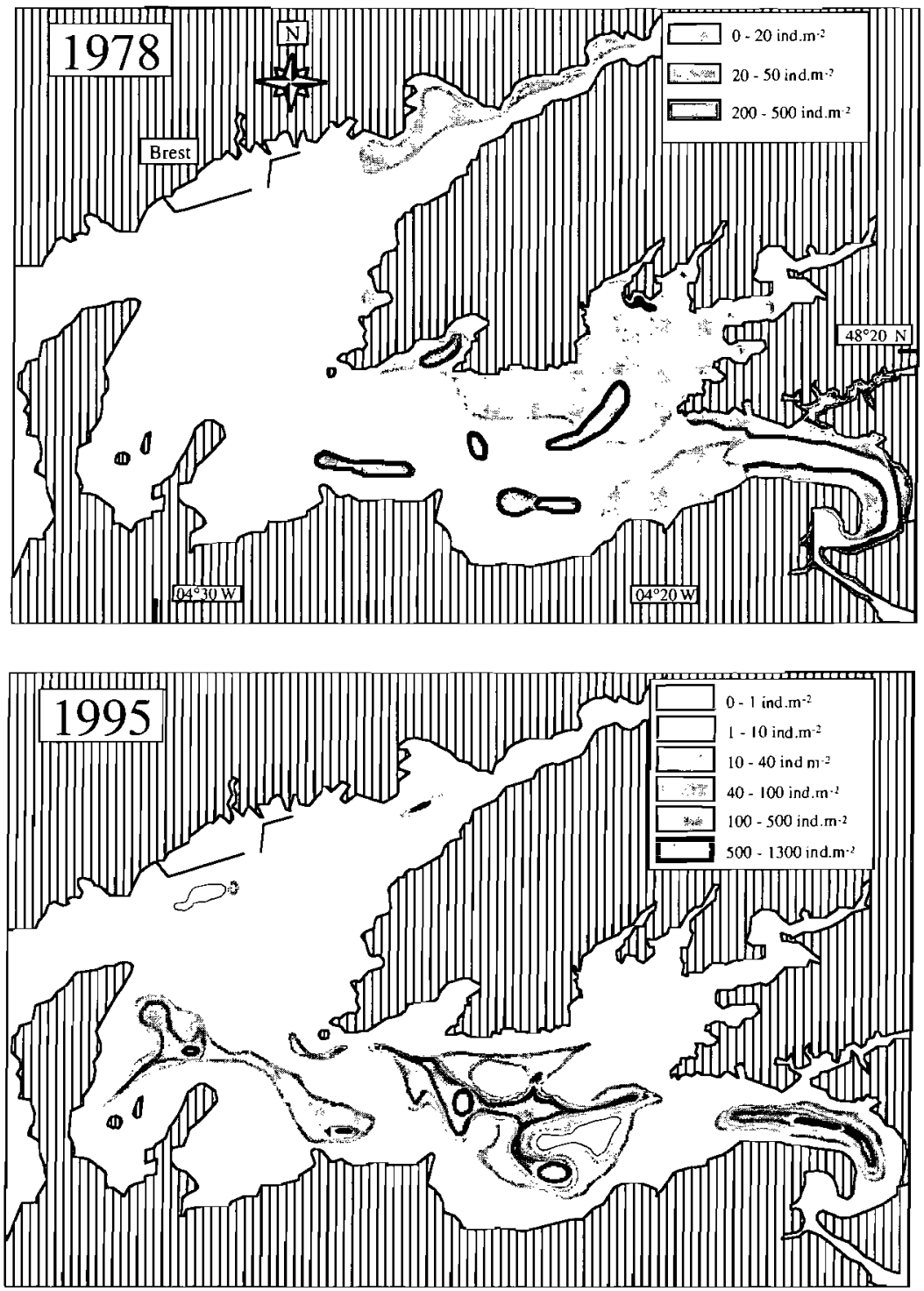

Fig. 7. Distribution (ind. $\mathrm{m}^{-2}$ ) of Crepidula fornicata in the Bay of Brest in 1978 (from Coum 1979) and in 1995 (modified from Chauvaud 1998) 
can be quantified. A comparison of the density and biomass of the communities living in these strata with the present Crepidula-based community highlights the increase of the suspension-feeder biomass within the latter community (Fig. 8). This biomass increase corresponds to a 101 -fold increase for colonised areas consisting of sand dunes and to a 570-fold increase for muds. Even though $C$. fornicata is mainly responsible for these increases, the biomass and density of other associated megafaunal suspension feeders have also increased since 1950, whereas species diversity among this trophic group remains stable at the biosedimentary stratum scale.

\section{Benthic-pelagic coupling}

One of the main features of the long-term chlorophyll biomass fluctuations in the Bay relates to the steady decrease of maximum chlorophyll concentration during the first spring bloom (Fig. 5). Such a trend could have different causes:

(1) Variable sampling scheme. A variable sampling frequency in spring would not enable one to systematically obtain chl a concentrations corresponding to the true maximum of the first annual bloom. However, spring has systematically been the most investigated period and sampling frequency cannot be the source of chlorophyll biomass fluctuations that occurred throughout the first bloom. Table 1 shows that the number of samples collected over $1 \mathrm{yr}$ cannot be related to the interannual fluctuations of chl a maximum.

(2) Unfavourable variations in weather conditions (light and rain). River flow-rate fluctuations (indicator of rainfalls) between 1977 and 1995 do not show any specific trend. The decrease of both the sea-

Table 2. Concentrations $(\mu \mathrm{M})$ of dissolved inorganic nitrogen (DIN nitrate + nitrite + ammonium), silicic acid and phosphate measured in surface waters at Stn $R 3\left(48^{\circ} 20^{\prime} \mathrm{N}\right.$, $4^{\circ} 30^{\prime} \mathrm{W}$ ), just prior to the first spring bloom

\begin{tabular}{|lccc|}
\hline Year & DIN & Phosphate & Silicate \\
\hline 1977 & $40^{\mathrm{a}}$ & 0.4 & $15^{\mathrm{a}}$ \\
1981 & $19^{\mathrm{a}}$ & & $7^{\mathrm{a}}$ \\
1982 & $10^{\mathrm{a}}$ & & $5^{\mathrm{a}}$ \\
1991 & 28.8 & 0.49 & 8.75 \\
1992 & 15.7 & 0.45 & 3.59 \\
1993 & 24.9 & 0.2 & 6.29 \\
1994 & 29.3 & 0.43 & 8.69 \\
aEstimated from authors' values (see Table 1 for refer- \\
ences) \\
\multicolumn{4}{|c}{} \\
\hline
\end{tabular}
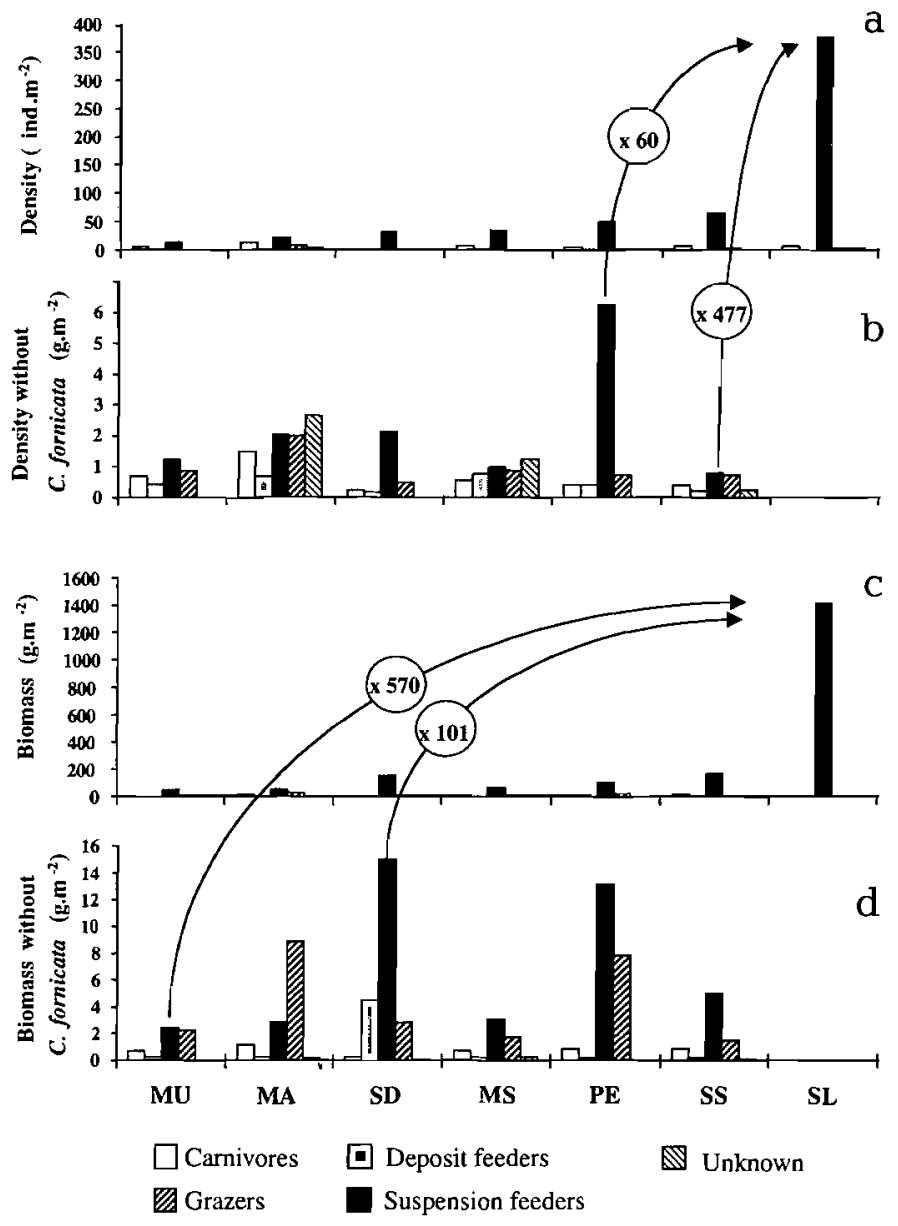

Fig. 8. Density and biomass of benthic megafaunal assemblages in each biosedimentary stratum. $(a, c)$ With Crepidula fornicata; (b,d) Without $C$. fornicata. MU: mud; MA: maerl; SD: sand dune; MS: muddy sand and gravel ${ }_{i}$ PE: pebbles; SS: sand shell; SL: slipper limpet

sonality index ( $\alpha$; Fig. 6) and chlorophyll biomass (Fig. 5) measured during the first annual spring bloom over the 1992 to 1995 period was concomitant with a steady increase in river flow rate (Fig. 2); this result could signify light limitation for primary production due to water-column stratification and increased turbidity.

(3) Changes in the species composition of spring blooms inducing a drastic decrease in phytoplankton production at this time of the year. Del Amo (1996) has reported large inter-annual variations in primary production since the $1980 \mathrm{~s}\left(280 \mathrm{~g} \mathrm{C} \mathrm{m}^{-2} \mathrm{yr}^{-1}\right.$ in 1981 ; Quéguiner \& Tréguer 1984; $255 \mathrm{~g} \mathrm{C} \mathrm{m}^{-2} \mathrm{yr}^{-1}$ in 1982 ; Hafsaoui 1984; $148 \mathrm{~g} \mathrm{C} \mathrm{m}^{-2} \mathrm{yr}^{-1}$ in 1993), but there has been no indication of increases in primary production. In addition, species composition of the first blooms was not radically modified between 1981 and 1993 (Del Amo et al. 1997b).

(4) Increased zooplankton grazing. In the Bay of Brest (Quéguiner 1982), like in many temperate coastal 
ecosystems (see Båmstedt 1985), the first spring bloom develops when zooplankton biomass is the lowest. Zooplankton grazing is thus negligible at this time of year.

(5) Reduction of nutrient concentrations before the first spring bloom. There is no indication of any longterm trends in nutrient concentrations (Table 2).

(6) Increasing suspension-feeder grazing. Increasing biomass of epibenthic suspension feeders would lead to increasing phytoplankton grazing by the benthos from year to year. It has been shown that when nutrient inputs in a coastal ecosystem increase while the production rate and species composition of phytoplankton populations are stable and suspension feeders biomass is growing, then the decrease of phytoplankton biomass can result from increasing benthic grazing. In particular, flume experiments (Oviatt et al. 1993, Peeters et al. 1993, Smaal et al. 1994) and in situ investigations conducted in lakes (Lehman 1980) and in coastal ecosystems (Cloern 1982, 1996, Motoda et al. 1987, Alpine \& Cloern 1992) have shown that phytoplankton biomass was controlled by the benthos in nutrient-enriched and shallow systems. Hily (1991) has suggested that, in the Bay of Brest, benthic suspension-feeding activity would be sufficient to explain the paradox observed by Quéguiner (1982) between high phytoplankton production and low chlorophyll biomass in summer. However, benthic grazing can totally control phytoplankton biomass only in the systems where the water residence time is long (several mo), as in the Bay of San Francisco (Cloern 1982, 1996, Officer et al. 1982). A mean residence time of about $25 \mathrm{~d}$ in the Bay of Brest (Anonymous 1980) could prevent total control of phytoplankton biomass by the benthos, but benthic grazing might explain the decrease in chlorophyll biomass during the first spring bloom of the annual cycle.

\section{Role of the benthos in the silicic acid pump (hypothesis)}

Most recent studies focusing on the role of silicic acid in phytoplankton dynamics in the Bay of Brest have shown (1) Si uptake limited by silicic acid availability in early spring (Del Amo 1996), (2) efficient retention of Si within the sediments of the Bay during spring (Ragueneau et al. 1994) and (3) the important role of vertical mixing in making silicic acid recycled at the sedimentwater interface available for diatoms in surface waters, despite a temporal decoupling between physical and biological processes (Ragueneau et al. 1996). Del Amo et al. (1997b) suggested that these processes together may be described as a 'silicic acid pump' that--in such a coastal, shallow and well-mixed ecosystem-would act differently than the scenario described by Dugdale et al. (1995) for stratified oceanic waters. The silicic acid pump mechanism restricts the potentially dramatic Si-limiting period and allows diatom production during summer, contrary to stratified deep-water systems, where silicic acid is depleted from the euphotic zone after spring bloom sedimentation (Del Amo et al. 1997b).

Our results suggest that benthic suspension-feeder activity may control the efficiency of this silicic acid pump in the Bay of Brest. We hypothesize that benthic filtration and biodeposition activities would (1) enhance BSi trapping and retention at the sedimentwater interface, (2) help BSi dissolution by biological activity (grazing) and (3) control the export rate of $\mathrm{BSi}$ towards the open-water ocean and thus the specific composition of secondary phytoplankton blooms in the Bay.

\section{DISCUSSION}

\section{Evidence for benthic grazing with seasonal fluctuations}

The feeding activity of benthic suspension feeders is highly influenced by the species composition and the intensity of phytoplankton blooms (Beukema \& Cadée 1991). Ingestion rate by suspension feeders is usually positively related to cell concentration in the water, up to a critical value (Winter 1977). Previous studies dealing with the Bay of Brest ecosystem (Le Pape 1996, Chauvaud 1998, Chauvaud et al. 1998) have shown that benthic suspension feeders consume only a part of the chlorophyll biomass. The amount of microalgae consumed can be detected when feeding activity of some species, or the whole trophic group, is stopped. With the exception of either toxic events or phytoplankton biomass in excess, the amount of phytoplankton cells in the water column does not limit Pecten maximus growth (Chauvaud et al. 1998). In 1994 and 1995, the spring shell growth of Age $1 P$. maximus restarted synchronously with the first Thalassiosira sp.-Cerataulina sp. bloom and coincided with maximum food intake (Chauvaud et al. 1998). Over the remainder of $1994, P$. maximus growth was not limited by low chl a concentrations and no competition for food between this species and other suspension feeders was evident (Chauvaud 1998). However, shell growth decreased during the following spring and summer blooms in 1995 (Fig. 9). Reduction in feeding and growth occurred because of toxicity of Gymnodinium blooms during June-September 1995, and gill clogging and termination of feeding (Chauvaud et al. 1998) or hypoxia when major Rhizosolenia delicatula-Chaetoceros sociale blooms developed. However, not all suspension feeders stopped feeding on these diatom 


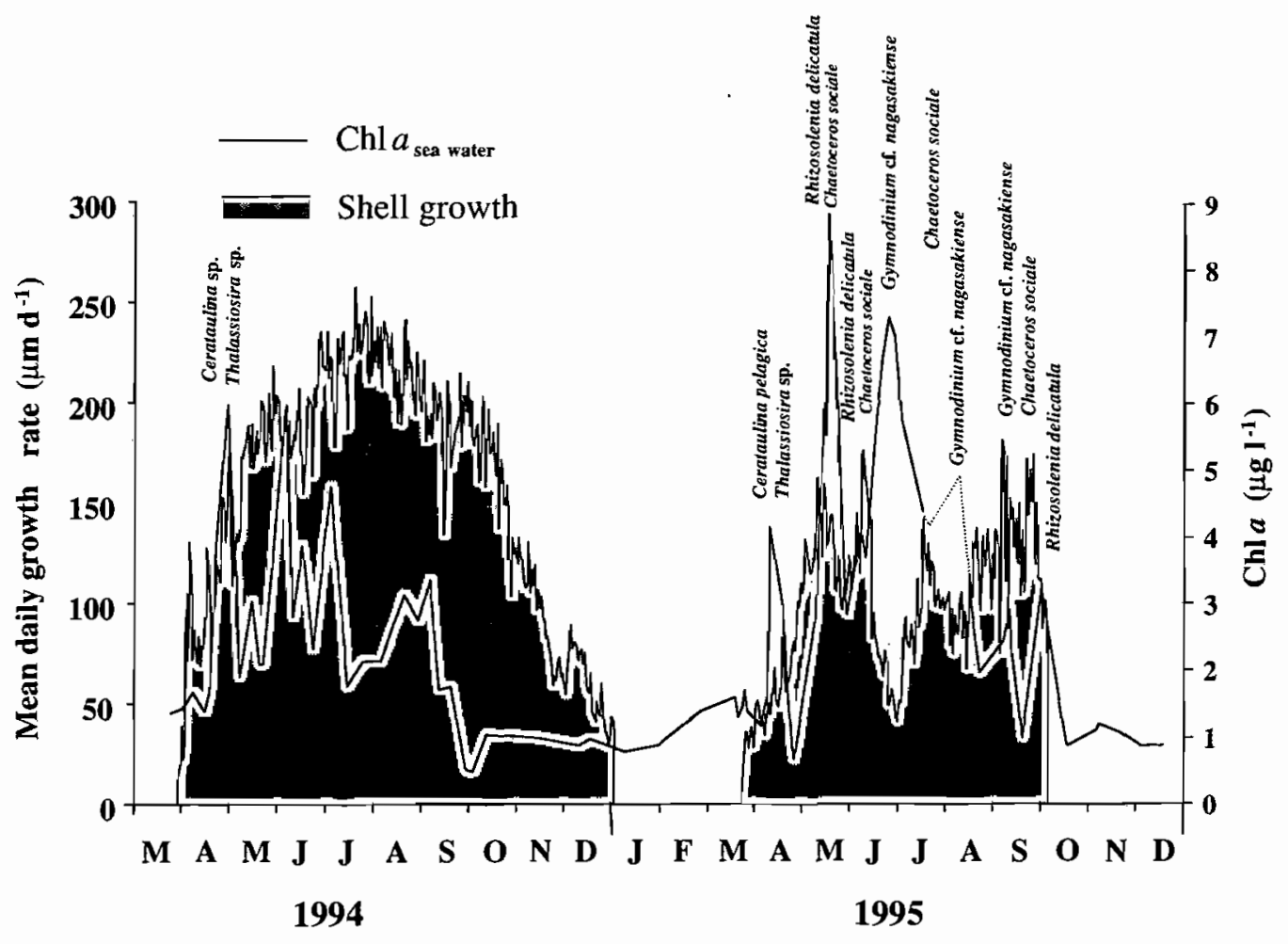

Fig. 9. Chl a concentrations $\left(\mu \mathrm{g}^{-1}\right)$ in bottom waters and mean daily growth rates $\left(\mu \mathrm{m} \mathrm{d}^{-1}\right)$ of Age 1 and Age 2 Pecten maximus juveniles (redrawn from Chauvaud et al. 1998). Main phytoplankton species are mentioned according to Nézan et al. (1996)

blooms. The high phaeophytin concentrations recorded in the water column during these events (Fig. 10) may partly result from zooplankton grazing. By contrast, during the Dinophysis (1993) and Gymnodinium (1995) toxic blooms, the bottom and surface chl a concentrations increased while phaeophytin concentrations were lowered (Fig. 10). Such phenomena may indicate that grazing by zooplankton (Poulet et al. 1994, Buskey \& Hyatt 1995) and/or benthos (Summerson \& Peterson 1990, this study) stopped completely.

\section{Evidence for enhanced BSi retention at the sediment-water interface?}

Active pumping and biodeposition by benthic suspension feeders are known to increase the downward particle fluxes near the sediment-water interface. De Vries \& Hopstaken (1984) have estimated that, in the Lake of Grevelingen (The Netherlands), biodeposition due to benthic suspension feeders would increase particulate matter fluxes to be 3 - to 4 -fold greater than those resulting from passive sedimentation. In the Bay of Brest, Barnes et al. (1973) stated that biodeposition by Crepidula fornicata and higher architectural complexity within C. fornicata

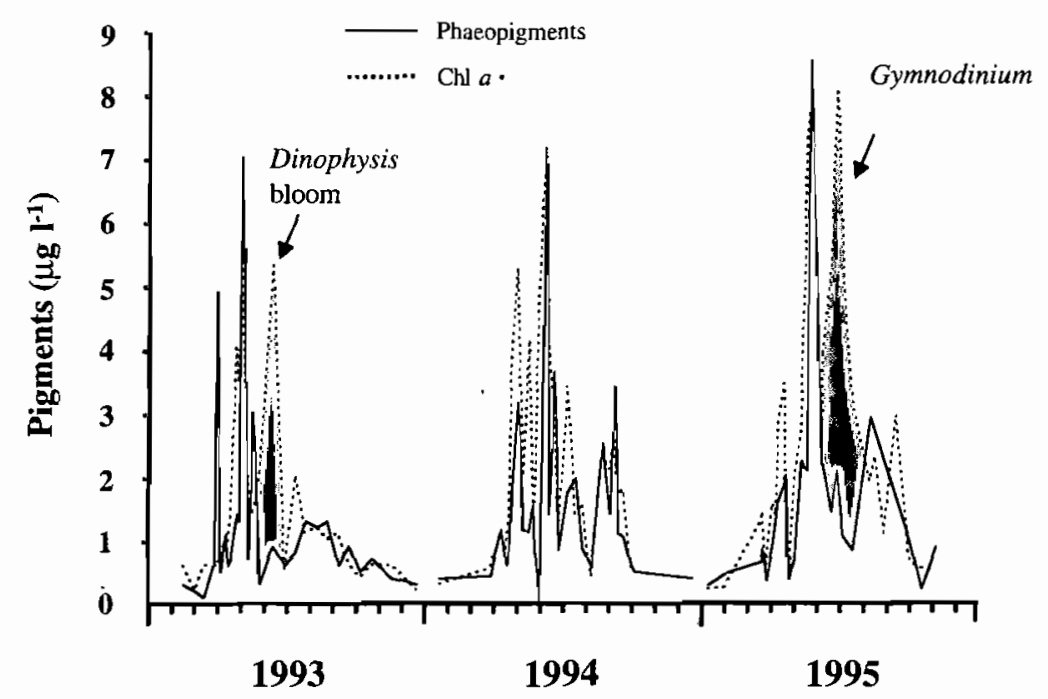

Fig. 10. Phaeophytin and chl $a$ concentrations $\left(\mu \mathrm{g} \mathrm{I}^{-1}\right)$ at $\operatorname{Stn} \mathrm{R} 3,1 \mathrm{~m}$ above the bottom. Unusual discrepancies between phaeophytin and chl a concentrations (shaded areas) indicate no phytoplankton grazing by zooplankton or benthic suspension feeders 
shoals led to siltation of sediment and reduced particle resuspension. C. fornicata has been reported to speed up the sedimentation process (Haven \& MoralesAlamo 1968, Newell 1979, Hamon \& Blanchard 1994], due to active pumping and biodeposit sedimentation rate being faster than that of other suspended matter (Haven \& Morales-Alamo 1968, Sornin 1981). Since biodeposits contain ca 22 to $26 \%$ organic matter (\% DW: Manac'h 1995), biodeposition leads to sediment organic-matter enrichment. In 1995, faeces and pseudo-faeces contained $3.5 \pm 1.1$ and $4.7 \pm 2.4 \mu \mathrm{g}$ chl a g ${ }^{-1}$ respectively (Manac'h 1995), which is higher than the concentrations usually found in upper sediment layers nearby ( 1 to $2 \mu \mathrm{g} \mathrm{g}^{-1}$; Riaux 1977, Sagan \& Thouzeau 1998). Therefore, C. fornicata feeding activities are likely to enhance BSi retention at the sediment-water interface.

\section{Can BSi recycling sustain diatom populations in late spring and summer?}

The maintenance of diatom populations in summer implies that the time required for BSi recycling is comparable to the time-scale of phytoplankton succession. The lowest specific rate for BSi dissolution in surface waters has been recorded in Antarctica $\left(3 \times 10^{-4} \mathrm{~h}^{-1}\right.$; Nelson \& Gordon 1982, Tréguer et al. 1989, Nelson et al. 1991) corresponding to a BSi residence time of nearly $3 \mathrm{mo}$. The highest values have been measured in tropical waters (5 to $8 \times 10^{-3} \mathrm{~h}^{-1}$; Nelson \& Goering 1977, Brzezinski \& Nelson 1989) and correspond to a residence time of ca $5 \mathrm{~d}$. Water temperature in the temperate Bay of Brest usually increases from 10 to $20^{\circ} \mathrm{C}$ from spring to summer. Disregarding any other factor liable to influence frustule dissolution, the residence time of BSi in the Bay of Brest sediments would be on the order of $1 \mathrm{mo}$. This pattern is in agreement with the spring Si budget estimated by Ragueneau et al. (1994), and corresponds to the increase of Si recycling from the sediment-water interface with temperature from April to June. Even though BSi reactivity in the sediment may be reduced by many processes involved during early diagenesis (see van Cappellen \& Qiu 1997), suspension-feeder activity is most likely to enhance BSi dissolution kinetics by removing the organic matter coating the opal surfaces, just like zooplankton (Miller et al. 1990) and bacteria (Jacobson \& Andersen 1986, Bidle \& Azam 1999). Thus, the timescale needed to mineralize BSi seems compatible to sustain diatom secondary blooms. Confirmation of enhanced silicic acid recycling due to benthic grazing can be inferred from a preliminary study conducted during summer 1997: a 2-fold increase of the silicic acid efflux from the sediment-water interface has been measured using a core incubation technique in the southern Basin as Crepidula fornicata biomass increases from 300 to $4600 \mathrm{~g} \mathrm{~m}^{-2}$ (WW; unpubl. data).

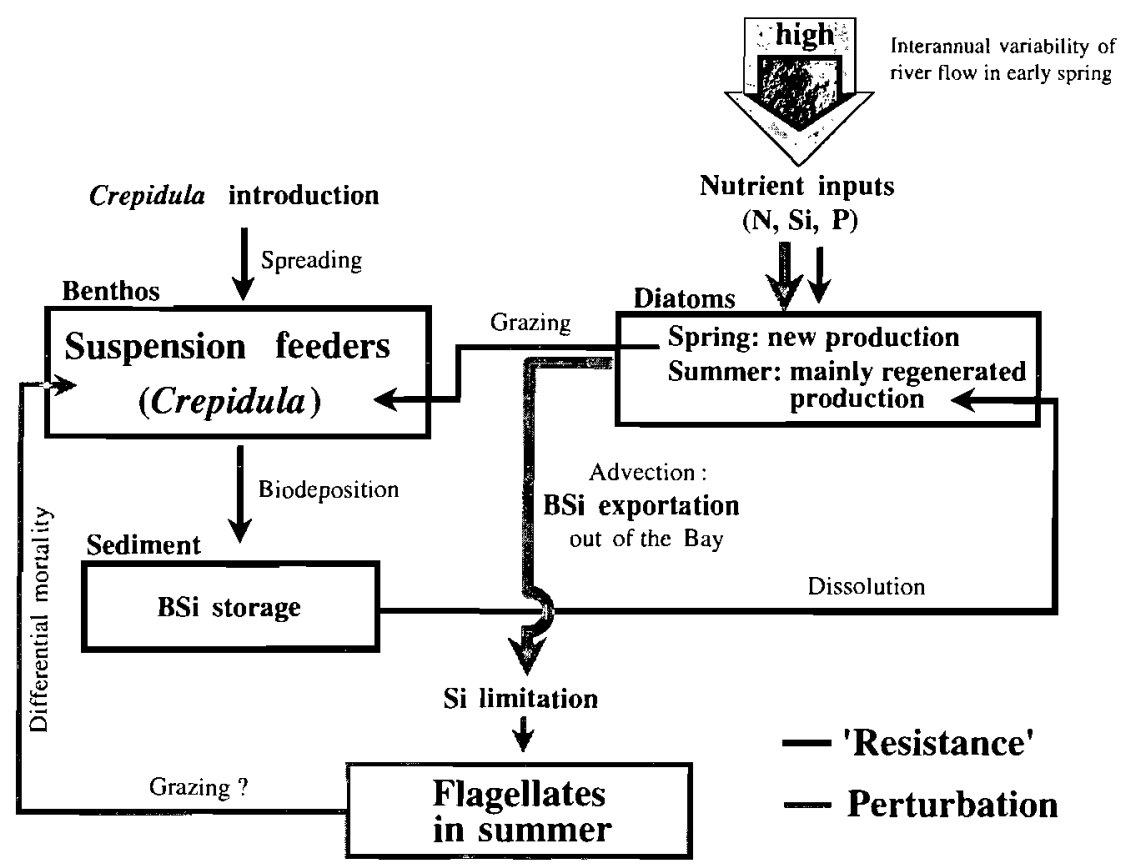

Fig. 11. Synthesis diagram highlighting the role of hydroclimatic conditions and benthic grazing on ecosystem functioning. Interannual variability of fluxes and process intensity is depicted by the variable thickness of arrows 


\section{Physical versus biological forcing}

From a pelagic point of view, the Bay of Brest seems to be resistant to the potentially negative effects of $\mathrm{N}$ enrichment. If several physical, chemical and biological factors can be advanced to explain such a resistance, the distrophy itself is a sign of potential nuisance blooms, as harmful phytoplankton blooms have been observed as a consequence of Si: $\mathrm{N}$ distrophy in many coastal areas (reviewed in Smayda 1990). The Bay of Brest would act as a differential filter for nutrients ( $N$ exportation vs Si retention) due to its hydrodynamic properties and biological activities. Such characteristics would explain the resistance of the bay to eutrophication of the pelagic system. However, the composition and intensity of secondary blooms would remain under the control of environmental conditions. Two scenarios may occur during the primary production period: (1) low or moderate rainfall (and thus river and nutrient discharges) in early spring would induce diatom-dominated phytoplankton successions in spring and summer similar to those observed in 1993 (e.g. March: Skeletonema costatum; April-May: Thalassiosira spp.-Rhizosolenia spp.; June-September: Chaetoceros spp-dinoflagellates; late September: cryptophyceans; Del Amo et al. 1997b) or in 1981 (Quéguiner 1982). Active filtration by benthic suspension feeders does occur in those cases. (2) Conversely, higher rainfall in early spring would be responsible for high spring phytoplankton biomass inhibiting suspension-feeder food intake either due to excessive food, too many inedible species or hypoxia. In that case, the ecosystem's ability to trap Si would dramatically drop, Si would be exported out of the Bay, thereby allowing dinoflagellates to develop in summer while $\mathrm{N}$ concentrations are still sufficient (e.g. in 1995; Fig. 11). It seems therefore evident that changes in the hydroclimatic conditions or in the benthic suspension feeder biomass are likely to influence phytoplankton biomass and species composition.

By contrast, in the absence of toxic blooms a longer primary production period, compared to $20 \mathrm{yr}$ ago, would favour the development of benthic suspension feeders (secondary production) and would explain why zoobenthic communities exhibit increasing biomass in the Bay of Brest. Such increases constitute the first level of disturbance in enriched coastal ecosystems (particulate organic matter enrichment-based disfunction, Type-2 benthic communities; Grall \& Glémarec 1997), associated with organic enrichment (Pearson \& Rosenberg 1978, Cederwall \& Elmgren 1990, Rosenberg et al. 1990). According to Gray (1992), the shallowest macrobenthic communities in the Bay (Daoulas Bay, Caro Cove) show initial symptoms of eutrophication, including a modified species composition (Grall \&
Glémarec 1997). Thus, the Bay of Brest displays significant disfunctioning at the benthos level.

The variable sensitivity of coastal ecosystems to nutrient enrichment can originate from the qualitative and quantitative variability of benthic systems (Cloern 1996). If benthic suspension feeders partly control phytoplankton biomass, and thus dampen the effects induced by increasing $\mathrm{N}$ input, regulation will depend on ecosystem depth, residence time, hydrodynamics and benthic community structure. Due to bottom types, the Bay of Brest benthic fauna is characterised by numerous assemblages with specific trophic structure, diversity and biomass (Hily 1989, Jean 1994, Jean \& Hily 1994, Jean \& Thouzeau 1995, Chauvaud et al 1996, Grall et al. 1996, Chauvaud 1998, Thouzeau et al in press). More than 130 benthic suspension-feeding taxa have been recorded in the Bay of Brest (Grall \& Chauvaud unpubl.). Such diversity would allow optimised consumption of pelagic primary producers, whatever the size of phytoplankton cells, and would contribute to the resistance of this ecosystem to eutrophication and toxic events. The proliferation of Crepidula fornicata, which is contemporary with increases in $\mathrm{N}$ input into the Bay of Brest, may have masked the changes that occurred in the ecosystem's functioning. If the apparent phytoplankton dynamics is the same today as it was 20 yr ago, the system's stability now depends not only on environmental conditions but also on benthic suspension-feeder activity.

Acknowledgements. This research was supported by a Contrat de Baie grant awarded by the Communauté Urbaine de Brest. We thank Yolanda Del Amo as well as 2 anonymous referees for their helpful comments. Thanks are also due to captains, officers, and crew members of the CIRMAT, IFREMER and Marine Nationale ships for their technical assistance at sea.

\section{LITERATURE CITED}

Alpine AE, Cloern JE (1992) Trophic interactions and direct physical effects control on phytoplankton biomass and production in an estuary. Limnol Oceanogr 37:946-955

Anderson DM (1995) Toxic red tides and harmful algal blooms: a practical challenge in coastal oceanography. US National Report to International Union of Geodesy and Geophysics 1991-1994, Rev Geophysics Suppl: 1189-1200

Anonymous (1980) Schéma d'aptitude et d'utilisation de la mer: rade de Brest. CNEXO/Unité Littoral-DDE, IFREMER, Brest

Båmstedt U (1985) Spring-bloom dynamics in Kosterfjorden, western Sweden: variation in phytoplankton production and macrozooplankton characteristics. Sarsia 70:69-82

Barnes RSK, Coughlan J, Holmes NJ (1973) A preliminary survey of the macroscopic bottom fauna of the Solent, with particular reference to Crepidula fornicata and Ostrea edulis. Proc Malacol Soc Lond 40:253-275 
Berger WH, Wefer G (1990) Export production: seasonality and intermittency, and paleoceanographic implications. Palaeogeogr Palaeoclimatol Palaeoecol (Global Planetary Change Suppl)89:245-254

Beukema JJ, Cadée GC (1991) Growth rates of the bivalve Macoma balthica in the Wadden Sea during a period of eutrophication: relationships with concentrations of pelagic diatoms and flagellates. Mar Ecol Prog Ser 68: 249-256

Bidle KD, Azam F (1999) Accelerated dissolution of diatom silica by marine bacterial assemblage. Nature 397 : 508-512

Billen G, Lancelot C, Meybeck M (1991) N, P, Si retention along the aquatic continuum from land to ocean. In: Mantoura RFC, Martin JM, Wollast R (eds) Ocean margin processes in global change. J Wiley \& Sons, New York, p 19-44

Billet DSM, Lampitt AL, Rice AL, Mantoura RFC (1983) Seasonal sedimentation of phytoplankton to deep-sea benthos. Nature 302:520-522

Bodeanu N (1990) Microalgal blooms in the Romanian area of the Black Sea and contemporary eutrophication conditions. In: Smayda TJ, Shimizu Y (eds) Toxic phytoplankton blooms in the Sea. Elsevier Science Publishers BV, Amsterdam, p 203-209

Breton H (1993) Etude des facteurs contrôlant la production primaire et la biomasse du phytoplancton en rade de Brest en période printanière: évolution comparée du microplancton, du nanoplancton et du picoplancton. Mémoire de DEA, Université de Bretagne Occidentale, Brest

Brzezinski MA, Nelson DM (1989) Seasonal changes in the silicon cycle within a Gulf Stream warm-core ring. DeepSea Res 36:1009-1030

Buskey EJ, Hyatt CJ (1995) Effects of Texas (USA) brown tide algae on planktonic grazers. Mar Ecol Prog Ser 126: 285-292

Cann C (1995) Flux de nutriments d'origine agricole. Actes colloque 3ème Rencontres Scient. Internationales Contrat de Baie-Rade de Brest 2:139-150

Cederwall H, Elmgren R (1990) Biological effects of eutrophication in the Baltic Sea, particularly the costal zone. Ambio 19:109-112

Chauvaud L (1998) La coquille Saint-Jacques en Rade de Brest: un modèle biologique d'étude des réponses de la faune benthique aux fluctuations de l'environnement. Thèse de doctorat, Université Bretagne Occidentale, Brest

Chauvaud L, Thouzeau G, Grall J (1996) Experimental collection of great scallop postlarvae and other benthic species in the Bay of Brest: settlement patterns in relation to spatio-temporal variability of environmental factors. Aquacult Int $4: 263-288$

Chauvaud L, Thouzeau G, Paulet YM (1998) Effects of environmental factors on the daily growth rate of Pecten maximus juveniles in the Bay of Brest. J Exp Mar Biol Ecol $227(1): 83-111$

Cloern JE (1982) Does the benthos control phytoplankton biomass in south San Francisco Bay? Mar Ecol Prog Ser 9: 191-202

Cloern JE (1996) Phytoplankton bloom dynamics in coastal ecosystems; a review with some general lessons from sustained investigation of San Francisco Bay, California. Rev Geophys 34:127-168

Conley DJ, Malone TC (1992) Annual cycle of dissolved silicic acid in Chesapeake Bay: implications for the production and fate of phytoplankton biomass. Mar Ecol Prog Ser 81: $121-128$
Coum A (1979) La population de crépidules Crepidula fornicata (L.) en rade de Brest: écologie et dynamique. Thèse de doctorat, Université Bretagne Occidentale, Brest

Daniel A (1995) Le cycle de l'azote en écosystème cotier: développement d'un analyseur submersible pour la mesure in situ des nitrates et nitrites; variations saisonnières de la production azotée phytoplanctonique. Thèse de doctorat, Université de Bretagne Occidentale, Brest

Daniel A, Birot D, Lehaitre M, Poncin J (1995) Characterisation and reduction of interferences in flow-injection analysis for the in situ determination of nitrate and nitrite in sea water. Anal Chim Acta 308:413-424

Dauchez S, Quéguiner B, Tréguer P, Zeyons C (1991) A comparative study of nitrogen uptake by phytoplankton in a coastal eutrophic ecosystem (Bay of Brest, France). Oceanol Acta 14:87-95

Del Amo Y (1996) Dynamique et structure des communautés phytoplanctoniques en écosystème cotier perturbé; cinétiques de l'incorporation de silicium par les diatomées. Thèse de doctorat, Université Bretagne Occidentale, Brest

Del Amo Y, Le Pape O, Tréguer P, Quéguiner B, Ménesguen A, Aminot A (1997a) The impacts of high-nitrate freshwater inputs on macrotidal ecosystems: I-Seasonal evolution of nutrient limitation for the diatom-dominated phytoplankton of the Bay of Brest (France). Mar Ecol Prog Ser 161:213-224

Del Amo $Y$, Quéguiner $B$, Tréguer $P$, Breton $H_{1}$ Lampert L (1997b) The impacts of high-nitrate freshwater inputs in macrotidal ecosystems: II - The specific role of the 'silicic acid pump' in the year-round dominance of diatoms in the Bay of Brest (France). Mar Ecol Prog Ser 161:225-237

Delmas R (1981) Etude de l'évolution saisonnière des sels nutritifs dans la rade de Brest en fonction des apports fluviaux et des échanges avec l'Iroise. Thèse de doctorat, Université Bretagne Occidentale, Brest

Delmas R, Tréguer P (1983) Evolution saisonnière des nutriments dans un écosystème eutrophe d'Europe Occidentale (la rade de Brest). Interactions marines et terrestres. Oceanol Acta 6:345-355

Deuser WG, Ross EH, Anderson RF (1981) Seasonality in the supply of sediment to the deep Sargasso Sea and implications for rapid transfer of matter to the deep ocean. DeepSea Res 28A:495-505

De Vries AJ, Hopstaken H (1984) Role of biodeposition by benthic suspension feeders on sedimentation processes. Neth J Sea Res 18:221-245

Dugdale RC, Wilkerson FP, Minas HJ (1995) The role of silicate pump in driving new production. Deep-Sea Res 42 : 697-719

Fisher TR, Peel ER, Ammerman JW, Harding LW Jr (1992) Nutrient limitation of phytoplankton in Chesapeake Bay. Mar Ecol Prog Ser 82:51-63

Graf G (1989) Benthic-pelagic coupling in a deep-sea benthic community. Nature 341:437-439

Grall J, Glémarec M (1997) Using biotic indices to estimate macrobenthic community perturbation in the Bay of Brest. Estuar Coast Shelf Sci 44:43-53

Grall J, Chauvaud L, Thouzeau G, Fifas S, Glémarec M, Paulet YM (1996) Distribution de Pecten maximus (L.) et de ses principaux compétiteurs et prédateurs potentiels en rade de Brest. C R Acad Sci Paris 319:931-937

Gray JS (1992) Eutrophication in the sea. In: Colombo G, Ferrari I, Ceccherelli VU, Rossi R (eds) Marine eutrophication and population dynamics. Proc 25th Eur Mar Biol Symp, Ferrara, Olsen \& Olsen, Fredensborg, p 3-15

Hafsaoui M (1984) Fertilisation d'un système eutrophe à forte variabilité saisonnière et annuelle (rade de Brest). Mise 
en évidence des facteurs limitants de la production phytoplanctonique. Assimilation simultanée des différentes formes d'azote inorganique et organique. Thèse.doctorat Université Bretagne Occidentale, Brest

Hamon D, Blanchard M (1994) Etat de la prolifération de la crépidule (Crepidula fornicata) en baie de Saint-Brieuc. Rapport lFREMER-DEL no. 94-14

Haven DS, Morales-Alamo R (1968) Occurrence and transport of faecal pellets in a tidal estuary. Sediment Geol 2: $144-151$

Herman PMJ, Scholten H (1990) Can suspension feeders stabilise estuarine ecosystem? In: Barnes M, Gibson RN (eds) Trophic relationships in the marine environment. Proc 24th Eur Mar Biol Symp, Oban, 4-10 October, 1989. Aberdeen University Press, Aberdeen, p 104-116

Hily C (1984) Variabilité de la macrofaune benthique dans les milieux hypertrophiques de la rade de Brest. Thèse de doctorat, Université Bretagne Occidentale, Brest

Hily C (1989) La mégafaune benthique des fonds meubles de la rade de Brest: pré-échantillonnage par vidéo sousmarine. Cah Biol Mar 30:433-454

Hily $C$ (1991) Is the activity of benthic suspension feeders a factor controlling water quality in the Bay of Brest? Mar Ecol Prog Ser 69:179-188

Hopkinson CS Jr (1987). Nutrient regeneration in shallowwater sediments of the estuarine plume region of the nearrshore Georgia Bight, USA. Mar Biol 94:127-142

Humborg C, lttekkot V, Cociasu A, von Bodungen B (1997) Effect of Danube River dam on Black Sea biogeochemistry and ecosystem structure. Nature 326:385-388

Jacobson DM, Anderson DM (1986) Thecate heterotrophic dinoflagellates: feeding behavior and mechanism. J Phycol 22:249-258

Jean F (1994) Modélisation à l'état stable des transferts de carbone dans le réseau trophique benthique de la rade de Brest (France). Thèse de doctorat, Université Bretagne Occidentale, Brest

Jean F, Hily C (1994) Quantitative sampling of soft-bottom macroepifauna for assessing the benthic system in the Bay of Brest (France). Oceanol Acta 17:319-330

Jean' F, Thouzeau G (1995) Estimation des variables d'état d'un modèle de réseau trophique benthique en rade de Brest. C R Acad Sci Paris Sci Vie 318:145-154

Joanny M, Belin C, Claisse D, Miossec L, Berthome JP, Grouhel A, Raffin B (1993) Qualité du milieu marin littoral. IFREMER, Plouzané

Le Pape O (1996) Modélisation des cycles biogéochimiques des éléments limitant la production phytoplanctonique en rade de Brest. Thèse de Doctorat, Ecole Nationale Supérieure d'Agronomie de Rennes, Rennes

Le Pape O, Del Amo Y, Ménesguen A, Aminot A, Quéguiner $B$, Tréguer $P$ (1996) Resistance of a costal ecosystem to increasing eutrophic conditions: the Bay of Brest (France), a semi-enclosed zone of western Europe. Cont Shelf Res 16:1885-1907

Lehman JT (1980) Physical and chemical factors affecting the seasonal abundance of Asterionella formasa hass in small temperate lake. Arch Hydrobiol 87(3):274-303

Loo LO, Rosenberg R (1989) Bivalve suspension-feeding dynamics and benthic-pelagic coupling in an eutrophicated marine bay. J Exp Mar Biol Ecol 130:253-276

Lorenzen CJ (1967) Determination of chlorophyll and phaeophytin: spectrophotometric equation. Limnol Oceanogr 12:343-346

Manac' h N (1995) La biodéposition de la crépidule (Crepidula fornicata). lmpact sur l'écosystème de la rade de Brest. Rapport IFREMER-DEL no. 95-15
Margalef R (1978) Life-forms of phytoplankton as survival alternatives in an unstable environment. Oceanol Acta 1: 493-509

Meybeck M, Helmer R (1989) The quality of rivers: from pristine stage to global pollution. Palaeogeogr Palaeoclimatol Palaeoecol 75:283-309

Miller CB, Nelson DM, Weiss C, Soeldner AH (1990) Morphogenesis of opal teeth in calanoid copepods. Mar Biol 106: $91-101$

Motoda S, Kotori M, Tahara H (1987) Long-term phytoplankton changes in Oshoro Bay, Kokkaido, and Matoya Bay, central Honshu, Japan. Bull Mar Sci 41:523-530

Nelson DM, Goering JJ (1977) Near-surface silica dissolution in the upwelling region off northwest Africa upwelling systems. Limnol Oceanogr 23:508-517

Nelson DM, Gordon LI (1982) Production and pelagic dissolution of biogenic silica in the Southern Ocean. Geochim Cosmochim Acta 46:491-501

Nelson DM, Ahern JA, Herlihy LJ (1991) Cycling of biogenic silica within the upper water column of the Ross Sea. Mar Chem 35:461-476

Newell RE (1979) Biology of intertidal animals. Marine Ecology Surveys Ltd, London

Nézan E, Arzul G, Bodennec G, Erard-Le Denn E, Gentien P, Lassus P, Marcaillou-Le Baut C, Ryckaert M (1996) Suivi du phytoplancton en rade de Brest et synthèse des connaissances sur les dinoflagellés nuisibles. Publ Spéc CUB Brest

Nichols FJ (1985) Increased benthic grazing: an alternative explanation for low phytoplankton biomass in northern San Francisco during the drought. Estuar Coast Shelf Sci 21:379-388

Nixon FH (1981) Remineralization and nutrient cycling in coastal marine systems. In: Neilson BJ, Cronin LE (eds) Estuaries and nutrients. Humana Press, New York, NJ, p 111-138

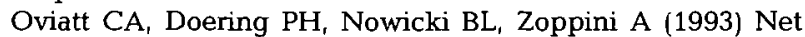
system production in coastal waters as a function of eutrophication, seasonality and benthic macrofaunal abundance. Estuaries 16:247-254

Officer CB, Ryther JH (1980) The possible importance of silicon in marine eutrophication. Mar Ecol Prog Ser 3:83-91

Officer CB, Smayda TJ, Mann R (1982) Benthic filter feeding: a natural eutrophication control. Mar Ecol Prog Ser 9: 203-210

Ott JA (1981) Adaptative strategies at the ecosystem level: examples from two benthic marine systems. PSZN I: Mar Ecol 2:113-158

Ott JA, Fedia K (1977) Stabilizing properties of a high-biomass benthic community in a fluctuating ecosystem. Helgol Wiss Meeresunters 30:485-494

Pearson $\mathrm{TH}_{1}$ Rosenberg $\mathrm{R}$ (1978) Macrobenthic succession in relation to organic enrichment and pollution of the marine environment. Oceanogr Mar Biol Annu Rev 16:229-311

Peeters JCH, Joordens JCA, Smaal AC, Nienhuis PH (1993) The impact of marine eutrophication on phytoplankton and benthic suspension feeders: results of mesocosm pilot study. Report DGW 930039, NIOO/CEMO-654

Pomroy AJ, Joint IR, Clarke KR (1983) Benthic nutrient flux in a shallow coastal environment. Oecologia 60:306-312

Poulet SA, Ianora A, Miralto A, Meijer L (1994) Do diatoms arrest embryonic development in copepods? Mar Ecol Prog Ser 111:79-86

Quéguiner B (1982) Variations qualitatives et quantitatives du phytoplancton dans un écosystème eutrophe fortement soumis aux effets des marées: La rade de Brest. Thèse 3ème cycle, Université Bretagne Occidentale, Brest 
Quéguiner B, Tréguer P (1984) Studies on the phytoplankton in the Bay of Brest (western Europe). Seasonal variations in composition, biomass and production in relation to hydrological and chemical features (1981-1982). Bot Mar $27: 449-459$

Ragueneau O (1994) La dynamique du phytoplancton en écosystèmes macrotidaux: couplage avec l'hydrodynamique et le cycle biogéochimique du Silicium. Thèse de doctorat, Université Bretagne Occidentale, Brest

Ragueneau O, De Blas Varela E, Tréguer P, Quéguiner B, Del Amo Y (1994) Phytoplankton dynamics in relation to the biogeochemical cycle of silicon in a costal ecosystem of western Europe. Mar Ecol Prog Ser 106:157-172

Ragueneau O, Quéguiner B, Tréguer P (1996) Contrast in biological responses to tidally-induced vertical mixing for two macrotidal ecosystems of western Europe. Estuar Coast Shelf Sci 42(5):645-665

Riaux C (1977) Contribution à l'étude de facteurs déterminants l'évolution de la biomasse phytoplanctonique dans l'estuaire de la Penzé (Nord Finistère). Evolution comparée des phénomènes dans l'eau et les sédiments sousjacents. Thèse de doctorat, Université Paris VI

Rosenberg R, Elmgren R, Fleischer S, Jonsson P, Persson G, Dahlin $\mathrm{H}$ (1990) Introduction-marine eutrophication in Sweden. Ambio 19:102-108

Sagan G, Thouzeau G (1998) Variabilité spatio-temporelle de la biomasse microphytobenthique en rade de Brest. Oceanol Acta 21 (5):677-694

Salomon JC, Breton M (1991) Numerical study of the dispersive capacity of the Bay of Brest, France, towards dissolved substances In: Cheung L (ed) Environmental hydraulics. Balkema, Rotterdam, p 459-464

Smaal AC, Peeters JCH, Haas HA, Heip CHR (1994) The impact of marine eutrophication on phytoplankton and benthic suspension feeders. Prog rep RIKZ 94035NIOO/CEMO

Smayda TJ (1990) Novel and nuisance phytoplankton blooms in the sea: evidence for a global epidemia. In: Graneli E (ed) Toxic marine phytoplankton. Elsevier Science Publishing Co, New York, p 29-40

Sornin JM (1981) Processus sédimentaires et biodéposition liés à différents types de conchyliculture. Thèse de doctorat, Université de Nantes, Nantes

Editorial responsibility: Otto Kinne (Editor),

Oldendorf/Luhe, Germany
Summerson HC, Peterson CH (1990) Recruitment failure of the bay scallop, Argopecten irradians concentricus, during the first red tide, Ptychodiscus brevis, outbreak recorded in North Carolina. Estuaries 13:322-331

Thouzeau G (1989) Déterminisme du pré-recrutement de Pecten maximus (L.) en baie de Saint-Brieuc. Thèse de doctorat, Université Bretagne Occidentale, Brest

Thouzeau G, Hily C (1986) AQUAREVE: une technique nouvelle d'échantillonnage quantitatif de la macrofaune épibenthique des fonds meubles. Oceanol Acta 9:509-513

Thouzeau G, Lehay D (1988) Variabilité spatio-temporelle de la distribution, de la croissance et de la survie des juvéniles de Pecten maximus (L.) issus des pontes 1985, en baie de Saint-Brieuc. Oceanol Acta 11:267-284

Thouzeau G, Robert G, Ugarte R (1991) Faunal assemblages of benthic mega-invertebrates inhabiting sea scallop grounds from eastern Georges Bank, in relation to environmental factors. Mar Ecol Prog Ser 74:61-82

Thouzeau G, Chauvaud L, Grall J, Guérin L (in press) Rôle des interactions biotiques sur le devenir du pré-recrutement et la croissance de Pecten maximus (L.) en rade de Brest. C R Acad Sci Paris Sci Vie

Tréguer P, Quéguiner B (1989) Conservative and non conservative mixing of dissolved and particulate nitrogen compounds, with respects to seasonal variability, in a West European macrotidal estuary. Oceanol Acta 12:371-380

Tréguer P, Kamatani A, Gueneley S, Quéguiner B, (1989) Kinetics of dissolution of Antarctic diatom frustules and biogeochemical cycle of silicon in the Southern Ocean. Polar Biol 36:1217-1227

van Bennekom AJ, Gieskes WWC, Tijssen SB (1975) Eutrophication of Dutch coastal waters. Proc R Soc Lond (B): 359-374

van Cappellen P, Qiu L (1997) Biogenic silica dissolution in sediments of the Southern Ocean. I. Solubility. Deep-Sea Res 44(5): $1109-1128$

Winter JE (1977) A review of the knowledge of suspensionfeeding in lamellibranchiate bivalves, with special reference to artificial aquaculture systems. Aquaculture 13: $1-33$

Yentsch CS, Menzel DW (1963) A method for the determination of phytoplankton chlorophyll and phaeophytin by fluorescence. Deep-Sea Res 10:221-231

Submitted: September 22, 1998; Accepted: November 16, 1999 Proofs received from author(s): June 13, 2000 